\title{
Analisis Fungsi Kesatuan Penjagaan Laut dan Pantai (KPLP)/Indonesia Sea and Coast Guard Guna Penegakan Hukum Pelayaran Di Daerah Lingkungan Kerja dan Daerah Lingkungan Kepentingan Pelabuhan Tanjung Mas Semarang (Tinjauan Yuridis Undang - Undang No 17 Tentang Pelayaran)
}

\author{
Winarno $^{a}$, Romanda Annas Amrullah ${ }^{b}$ \\ ${ }^{\text {a,b }}$ Politeknik Ilmu Pelayaran Semarang \\ aEmail: whien34@yahoo.co.id
}

\begin{abstract}
ABSTRAK
Pada pemerintahan Presiden Jokowi Widodo telah menetapkan kebijakan kemaritiman national melalui konsep Indonesia sebagai Poros Maritim Dunia (PMD). Konsep ini disampaikan Presiden Jokowi Widodo pada Konferensi Tingkat Tinggi (KTT) ke-9 East Asia Summit (EAS), 13 November 2014 . Keamanan maritim bukan hanya menjadi tugas pokok Angkatan Laut sebagai tulang punggung penyangga utama kemanan maritim sebuah negara, tetapi tidak lepas dari dukungan instansi non militer (sipil) yang tugas dan fungsinya melekat erat pada aspekaspek pengawasan keamanan dan keselamatan maritim dalam hal ini adalah Coast Guard (Penjaga Pantai). Penelitian ini merupakan penelitian kualitatif dan menggunakan analisis diskriptif yang ditujukan untuk mendeskripsikan tugas dan permasalahan yang dihadapi Kesatuan Penjagaan Laut dan Pantai sebagai Sea and Coast Guard di Daerah Lingkungan Kerja (DLKr) dan Daerah Lingkungan Kepentingan (DLKp) Pelabuhan Tanjung Mas Semarang, serta berkaitan dengan kebijakan yang diambil KSOP Tanjung Mas Semarang dalam mengatasi permasalahan yang timbul di lapangan terkait fungsi KPLP dengan berdasarkan UndangUndang Nomor 17 tahun 2008 tentang Pelayaran.
\end{abstract}

Kata Kunci : Keamanan maritime, kualitatif, diskriptif.

\section{PENDAHULUAN}

Fungsi Kesatuan Penjagaan Laut dan Pantai (KPLP) merupakan Kesatuan Penjagaan Laut dan Pantai Republik Indonesia atau Indonesia Sea and Coast Guard merupakan Direktorat dibawah Direktorat Jenderal Perhubungan Laut, Kementerian Perhubungan Republik Indonesia yang bertugas mengamankan pelayaran di Indonesia. Adapun semboyan KPLP adalah "Dharma Jala Praja Tama" artinya "Sebagai insan bahari selalu berusaha menjalankan pengabdian yang terbaik untuk bangsa dan negara.

Keberadaan Kesatuan Penjagaan Laut dan Pantai di Indonesia memiliki landasan hukum yakni Peraturan Pelayaran (Scheepvaart Reglement) LN.1882 No.115 junto LN.1911 No.399

https://doi.org/10.46484/db.v1i1.187
(Kepolisian di Laut). Undang-Undang Pelayaran (Scheepvaart Ordonantie) 1936 ( Stb.1936 No.700 ), Peraturan Pelayaran 1936 pasal 4 , dan Ordonansi Laut Teritorial dan Lingkungan Maritime 1939 Pasal 13.

Era Revulusi Industri 4.0 sekarang ini, Indonesia dituntut untuk meningkatkan pelayanan yang prima dengan mengutamakan Keamanan sebagai wujud kehormatan negara. Keamanan maritim bukan hanya menjadi tugas pokok Angkatan Laut sebagai tulang punggung penyangga utama kemanan maritim sebuah negara, tetapi tidak lepas dari dukungan instansi non militer (sipil) yang tugas dan fungsinya melekat erat pada aspek-aspek pengawasan keamanan dan keselamatan maritim dalam hal ini adalah Coast Guard (Penjaga Pantai) karena aspek- 
aspek tersebut secara teknis bukan merupakan yuridiksi Angkatan Laut. Organisasi Coast Guard dimiliki oleh semua negara yang mempunyai wilayah laut walaupun dengan penamaan yang berbeda-beda.

Wilayah perairan suatu pelabuhan merupakan daerah tempat lalu lintas kapal baik untuk kegiatan ekonomi seperti pelayaran niaga maupun kegiatan non ekonomi seperti kegiatan pemerintah baik kapal negara maupun kegiatan pemerintah lain. Dalam kegiatan lalu lintas di perairan pelabuhan dibutuhkan pengawasan guna memastikan kegiatan berlangsung tertib, aman, dan menimbulkan dampak ekonomi yang menguntungkan. Untuk itu diperlukan keberadaan aparat pemerintah fungsi non militer (kombatan) yang mempunyai tugas khusus dalam mengawasi kegiatan ini dengan berpegang atau didasarkan kepada hukum khusus (lex specialis).

Dalam Undang Undang Nomor 17 Tahun 2008 tentang Pelayaran tertulis, Daerah Lingkungan Kerja (DLKr) adalah wilayah perairan dan daratan pada pelabuhan atau terminal khusus yang digunakan secara langsung untuk kegiatan pelabuhan. Sedangkan, Daerah Lingkungan Kepentingan (DLKp) adalah perairan di sekeliling daerah lingkungan kerja perairan pelabuhan yang dipergunakan untuk menjamin keselamatan pelayaran. DLKr meliputi wilayah daratan dan perairan, sementara DLKp hanya meliputi wilayah perairan. Pengawasan dan pengendalian terhadap DLKr dan DLKp perairan pelabuhan di Indonesia dilaksanakan oleh Kesatuan Penjagaan Laut dan Pantai (KPLP) yaitu sebuah organisasi para militer milik pemerintah di bawah Direktorat Jenderal Perhubungan Laut (DJPL) Kementerian Perhubungan yang tugasnya menjamin terselenggaranya keselamatan dan keamanan di laut dan pantai (Pasal 276 Ayat (1) UU 17 Tahun 2008). Dalam Bab XVII UU 17 Tahun 2008 dituliskan pula bahwa KPLP adalah sebagai Sea and Coast Guard yang dibentuk dan bertanggung jawab kepada Presiden yang secara teknis operasional dilaksanakan oleh Mentari Perhubungan (Pasal 276 Ayat (3)) yang artinya dalam melaksanakan kegiatan dan pembiayaan adalah di bawah pembinaan Menteri Perhubungan.

Akan tetapi dalam melaksanakan tugasnya KPLP tentu mengalami berbagai masalah dan hambatan terutama dalam melaksanakan penegakan hukum pelayaran dalam hal ini adalah UU No. 17 Tahun 2008 tentang Pelayaran maupun peraturan lain dalam bidang pelayaran baik skala nasional maupun internasional. Permasalahan dalam penelitian ini dibagi ke dalam beberapa hal, yaitu (1)bagaimanakah gambaran umum tugas Kesatuan Penjagaan Laut dan Pantai sebagai Sea and Coast Guard di Daerah Lingkungan Kerja (DLKr) dan Daerah Lingkungan Kepentingan (DLKp) Pelabuhan Tanjung Mas Semarang saat ini, (2)bagaimana Permasalahan yang sering dihadapi dalam melaksanakan fungsi penegakan hukum pelayaran di DLKr dan DLKp Pelabuhan Tanjung Mas Semarang, (3)bagaimanakah kebijakan yang diambil KSOP Tanjung Mas Semarang dalam mengatasi permasalahan yang timbul di lapangan terkait fungsi KPLP dengan berdasarkan Undang-Undang Nomor 17 tahun 2008 tentang Pelayaran. Adapun tujuan dari penelitian ini adalah untuk (1)mengetahui gambaran umum tugas Kesatuan Penjagaan Laut dan Pantai sebagai Sea and Coast Guard di Daerah Lingkungan Kerja (DLKr) dan Daerah Lingkungan Kepentingan (DLKp) Pelabuhan Tanjung Mas Semarang saat ini, (2)untuk mengetahui dan menganalisa permasalahan yang dihadapi dalam melaksanakan fungsi penegakan hukum pelayaran di DLKr dan DLKp Pelabuhan Tanjung Mas Semarang, (3)untuk memberikan masukan dan pertimbangan terhadap kebijakan yang diambil KSOP Tanjung Mas Semarang dalam mengatasi permasalahan yang timbul di lapangan 
ISSN : 2087-3050

e-ISSN : 2722-0621

terkait fungsi KPLP dengan berdasarkan Undang-Undang Nomor 17 tahun 2008 tentang Pelayaran.

\section{METODE PENELITIAN}

Penelitian ini merupakan penelitian kualitatif yang teknik pengumpulan data dalam penelitian ini menggunakan:Angket (Questionnaire) kepada para anggota Kesatuan Penjagaan laut dan Pantai (KPLP) KSOP Pelabuhan Tanjung Mas Semarang, Wawancara (Interview) dicatat atau direkam dalam hal ini bisa meliputi Para Perwira Kapal Patroli KPLP dan Anak Buah Kapal Patroli KPLP, Observasi (pengamatan) meliputi pemusatan perhatian terhadap suatu obyek dengan menggunakan seluruh alat indra.

Analisis data yang digunakan oleh Peneliti adalah menggunakan motode analisis deskriptif, menggambarkan kesimpulan sebagai jawaban terhadap permasalahan yang mempelajari masalah-masalah dalam masyarakat, serta tata cara yang berlaku dalam masyarakat serta situasi-situasi tertentu, termasuk tentang hubungan-hubungan, kegiatan-kegiatan, sikap- sikap, pandangan-pandangan, serta prosesproses yang sedang berlangsung dan pengaruh-pengaruh dari suatu fenomena.

\section{HASIL PENELITIAN DAN PEMBAHASAN}

1. Kendala KPLP melaksanakan tugas Patroli Maritim di wilayah hukum KSOP Tanjung Emas Semarang, diantaranya adalah:

a. Kurang maksimalnya dukungan KSOP, sebagaimana pendapat Erick " Dukungan yang diberikan masih dalam tahap wajar karna masih banyak yang harus dibenahi dari kapal patrol kita.

b. Fasilitas kapal yang berlayar yang belum memadai seperti kapal tidak layak untuk berlayar.

Sebagai mana hasil wawancara:

Kesulitan kita biasanya kita menemukan kesulitan saat
Dinamika Bahari

Vol.1 No.1 Edisi Mei 2020 : 39-44

menghadapi kapal yang tidak ada alat keselamatannya, disana kita harus menegurnya karena banyak kapal yang masih belum memenuhi syarat untuk aman, lalu fasilitas yang belum layak untuk kegiatan patrol, sedangkan dalam menjalankan tugas perlu peralatan yang memadahi sebagaimana Pasal 66 Undang-Undang Nomor 31 Tahun 2004 tentang Perikanan berikut penjelasannya.:

Untuk bidang perikanan, pengawasan mencakup kegiatankegiatan (i) pemantauan terhadap jumlah kapal perikanan dan alat yang dipergunakan menurut jenis dan ukurannya, ikan hasil tangkapan menurut jenisnya dan hari penangkapan menurut jenis kegiatan, serta terhadap daerah dan musim penangkapan ikan, (ii) pengendalian terhadap jumlah kapal perikanan dan alat penangkapan ikan yang diberikan izin menurut jenis dan ukurannya, dan (iii) pengawasan terhadap pelaksanaan ketentuan perizinan penangkapan ikan

c. Banyak beberapa peralatan dan fasilitas patrol yang kurang sempurna, dan rusak.

d. Ada beberapa personel yang kurang ilmu tentang patroli dan lain-lain, hal tersebut sebagaimana hasil wawancara dengan pegawai KPLP banyak fasilitas yang harus diperbaiki dari kapal patroli, safetynya, senjatanya bahkan keahlian kita perlu ada pelatihan lagi/ diklat.

2. Kebijakan KSOP Tanjung Emas Semarang dalam mengatasi permasalahan yang timbul di lapangan terkait fungsi KPLP.

Kebijakan tersebut dapat dilakukas secara procedural sesuai program maupun incidental sesuai dengan kebutuhan namun tidak jauh dari program yang telah di rencanakan, diantaranya adalah: 
a. Memberikan peneguran misalkan tidak lengkap dalam hal alat keamanan

b. Jika tidak mau melengkapi kekurangan maka akan dilaporkan kepada syah Bandar.

Hal tersebut sebagaimana wawancara dengan pegawai KPLP:

"Biasanya ada kapal yang tidak ada alat safetynya kita tegur dulu disuruh buat memenuhi alat tersebut, jika mereka tidak mau maka kita akan melaporkan ke syahbandar.

c. Selain itu KSOP juga memberikan Program Solusi, Bidang Keselamatan Berlayar, Penjagaan dan Patroli. Program tersebut terdiri dari beberapa tindakan yaitu:

1) melaksanakan pengawasan tertib lalulintas kapal di perairan pelabuhan dan alur pelayaran.

2) pemanduan dan penundaan kapal.

3) penerbitan Surat Persetujuan Berlayar.

4) kegiatan alih muat di perairan pelabuhan, salvage dan pekerjaan bawah air.

5) bongkar muatbarang berbahaya, barang khusus, pengisian bahan bakar, limbah bahan berbahaya dan beracun (B3).

6) ketertiban embarkasi dan debarkasi penumpang, pembangunan fasillitas pelabuhan, pengerukan dan reklamasi, pelaksanaan bantuan pencarian dan penyelamatan (Search And Rescue/SAR).

7) pengendalian dan koordinasi penanggulangan pencemaran dan pemadaman kebakaran di pelabuhan.

8) pelaksanaan perlindungan lingkungan maritime.
9) pelaksanaan pemeriksaandan verifikasi sistem keamanan kapal dan fasilitas pelabuhan (International Ship and Port Facility Security Code/ISPSCode).

10) pemeriksaan pendahuluan pada kecelakaan kapal.

11) penegakan hukum di bidang keselamatan dan keamanan pelayaran sertapelaksanaan koordinasi kegiatan pemerintahan di pelabuhan yang terkait dengan pelaksanaan pengawasan dan penegakan hukum di bidang keselamatan dan keamanan pelayaran.

\section{SIMPULAN}

Simpulan pada penelitian ini mengarah kepada menjawab permasalah yang sudah dirumuskan, adapun simpulan sebagai berikut:

1. Gambaran Umum Kegiatan patroli maritim KPLP di wilayah Tanjung Emas Semarang.

Proses kegiatan patroli di wilayah laut saat Kesatuan Penjagaan Laut dan Pantai (KPLP) melaksakan patroli laut :

a. Pola Operasi Patroli Umum

Setiap hari 2 kapal kapal bertugas / piket melaksanakan patroli secara bergantian selama 24 jam, Jam tugas / piket mulai pukul 08.00 s/d 08.00 hari berikutnya, Apabila diperlukan akan meminta bantuan dari instansi keamanan terkait yang ada di pelabuhan,

b. Pola Operasi Patroli Rutin

1) Patroli pelabuhan dan alur pelayaran, memastikan keadaan aman serta tidak ada nelayan yang menganggu kelancaran kapal keluar masuk pelabuhan.

2) Dekati nelayan, catat nama kapal, nama Nahkoda serta peringatkan untuk tidak 
memancing atau menebar jaring dikolam pelabuhan / alur pelayaran Mengawasi sarana bantu navigasi.

3) Monitor kegiatan kapal keluar masuk pelabuhan.

c. Pola Pengamanan Kapal Asing

1) Koordinasi dan komunikasi intensif dengan posko ISPS Codel Kepanduan tentang kedatangan dan keberangkatan kapal - kapal asing.

2) Jemput kedatangan kapal asing dari buoy luar alur pelayaran sehingga kapal sandar di TPKS.

3) Patroli secara berkala di alur pelayaran.

4) Pengawasan kapal asing selama sandar, untuk menghalau nelayan dan orang-orang yang tidak berkepentingan atau mencurigakan.

5) Jika kapal asing sedang lego jangkar, patroli akan dilakukan setiap 4 jam sekali.

6) Bila kapal asing yang meninggalkan pelabuhan dikawal hingga buoy luar.

2. Permasalahan-Permasalahan di KPLP Wilayah Tanjung Emas Semarang.

Berdasarkan permasalahan pada tabel pada bab sebelumnya, diketahui hampir setiap tahun selalu terjadi kecelakaan kapal di pelabuhan Tanjung Emas Semarang, kecelakaan itu mulai dari menabrak kapal nelayan, kapal tenggelam, kapal terbakar, kapal kandas, dan mengakibatkan banyak kerugian baik dari kerugian materiil maupun fisik kapal. Kemudian diselesaikan lewat jalur hukum yaitu, masuk kedalam sidang Mahkamah Pelayaran, yang bertujuan untuk menentukan pihak yang berhak untuk ganti rugi atas kecelakaan tersebut.
3. Penyelesaian Permasalahan dan Kebijakan.

Penyelesaian permasalahan dan kebijakan yang diambil adalah sebagai berikut:

a. Penambahan kualitas dan Peningkatan peralatan serta perlengkapan untuk kegiatan operasional keamanan dan ketertiban oleh KPLP seperti : pembaruan kapal patroli, persenjataan, alat komunikasidan perlengkapan penunjang yang lain.

b. Peningkatan kualitas pengetahuan, ketrampilan, keahlian dan kecakapan para petugas KPLP seperti : peningkatan ijazah keahlian pelaut, mengikuti diklat ketrampilan yang disediakan oleh Dirjen Hubla, melakukan latihan-latihan gabungan dengan instansi lain.

\section{DAFTAR PUSTAKA}

Bernhars Limbong, 2015, Poros Maritim, PT. Dharma Karsa Utama, Jakarta

International Convention For the Safety Of Life At Sea (SOLAS) 1974

Marsetio, 2014, Indonesian Sea Power, Indonesia Defence University, Jakarta

Peraturan Menteri Perhubungan Republik Indonesia Nomor 122 Tahun 2018 tentang Organisasi dan Tata Kerja Kementerian Perhubungan

Robert Mangindaan, 2014, Intelijen Maritim dan Upaya Memperkokoh Keamanan Maritim Indonesia, Createspace Independent Publishing Platform, California 
ISSN : 2087-3050

e-ISSN : 2722-0621

Sudaryono, 2017, Metodologi Penelitian, Jakarta: Rajawali Pers.

Tri Sulistyaningtyas, dkk, 2016, Sinergitas Paradigma Lintas Sektor di Bidang Keamanan dan Keselamatan Laut, Gramedia, Jakarta

Undang-Undang Republik Indonesia Nomor 17 Tahun 1985 tentang Pengesahan United Nations Convention on the Law Of the Sea (Konvensi Perserikatan Bangsa-Bangsa Tentang Hukum Laut)

Undang-Undang Republik Indonesia Nomor 17 Tahun 2008 tentang Pelayaran

Undang-Undang Republik Indonesia Nomor 32 Tahun 2014 tentang Kelautan

United Nations Convention on the Law Of the Sea 1982

Winarno, dkk, 2017, Konvensi Maritim, Politeknik Ilmu Pelayaran Semarang, Semarang.

Sudaryono, 2017, Metodologi Penelitian, Jakarta: Rajawali Pers.

Mukti Fajar, dkk, 2010, Dualisme Penelitian Hukum Normatif dan Empiris, (Yogyakarta: Pustaka Pelajar.

https//business-law.binus.ac.id. di akses 20 September 2019, tentang: Utilitarianisme dan Tujuan Perkembangan Hukum Multimedia di Indonesia
Dinamika Bahari

Vol.1 No.1 Edisi Mei 2020 : 39-44

\section{"ISCG-KPLP"}

Undang-Undang Nomor 17

Tahun 2008, dan baca http://www.dephub.go.id/post/re ad/.

ASRO Jurnal- STTAL , Analisa Peluang Dan Ancaman Keamanan Maritim Indonesia Sebagai Dampak Perkembangan Lingkungan Strategis Vol. 6 ; Jul-Des 2016.

Sudaryono, Metodologi Penelitian, Jakarta: Rajawali Pers, 2017, h. 91

Sukmadinata, Metode Penelitian Pendidikan, Bandung: Remaja Rosdakarya, 2009, h. 71

Suharsimi Arikunto, Prosedur Penelitian Suatu Pendekatan Prakter, (Jakarta: RinekaCipta, 2002), h.133.

Mukti Fajar, dkk, Dualisme Penelitian Hukum Normatif dan Empiris, (Yogyakarta: Pustaka Pelajar, 2010), h. 192

Moh.Nazir. Ph. D, MetodePenelitian (Jakarta: PT. Ghalia Indonesia, 2003), h.16

Erick Budi Saputro, Chief Officer, unit KNP 337, pada tanggal 20 Agustus 2019

Pasal 66 Undang-undang Nomor 31 Tahun 2004 tentang Perikanan

Hasil studi dokumen pada KSOP Tanjung Emas Semarang, pada www.ksoptanjungemas.com, diakses September 2018

www.kemenlu.go.id, United Nations Convention on the Law of the Sea (UNCLOS) article 11 